\title{
Naar een uniform arbeidscontract?
}

\author{
Olaf Tijhuis \& Kees Goudswaard*
}

Diverse landen hebben te maken met een sterke groei van flexibele arbeid en als gevolg daarvan onevenwichtigheden op de arbeidsmarkt. In dit verband zijn verschillende voorstellen gedaan om alle huidige arbeidscontracten te vervangen door één uniform arbeidscontract. In dit artikel brengen we de vormgeving van een dergelijk contract in kaart en analyseren we aan de hand van de literatuur mogelijke effecten. Verder besteden we aandacht aan de debatten in Frankrijk, Italië en Spanje over een uniform contract.

In de meeste voorstellen is de duur van het uniform contract onbepaald en zijn er twee fasen: een instapfase en een stabiliteitsfase. Tijdens de instapfase is ontslag gemakkelijk, maar de ontslagvergoeding loopt wel in de tijd op. Er zijn voor- en nadelen aan een dergelijk contract verbonden, maar de effecten op scholing en werkgelegenheid zijn waarschijnlijk per saldo positief. In de genoemde landen bleek het maatschappelijk draagvlak voor een uniform contract toch onvoldoende. Waarschijnlijk is dat ook in Nederland het geval, maar de voorstellen van het kabinet Rutte-III om de verschillen tussen flex en vast te verkleinen kennen wel punten van overeenstemming met het uniforme contract. Ook het middellange contract zou een interessante optie kunnen zijn.

\section{Inleiding}

Er zijn steeds minder vaste contracten op de Nederlandse arbeidsmarkt. Op dit moment hebben vier van de tien werkenden geen vast contract, twaalf jaar gelden waren dit er minder dan drie. Zowel de omvang van de flexibele schil als de groei van flexibele arbeid is in Nederland groter dan in andere Europese landen (Euwals, De Graaf-Zijl, \& Van Vuren, 2016). Het beeld leeft breed dat het evenwicht tussen vast en flex verstoord is en dat de arbeidsmarkt een sterk gesegmenteerd karakter heeft gekregen. Ook verschillende internationale instanties, zoals het IMF en de OESO, stellen dat Nederland is doorgeslagen in de flexibilisering, mede omdat de verschillen in sociale bescherming tussen vast en flex steeds groter worden. Daarom speelt de vraag hoe er een beter evenwicht tussen vast en flex op de Nederlandse arbeidsmarkt bereikt kan worden al jaren een belangrijke rol. De in 2016 ingevoerde Wet Werk en Zekerheid (WWZ) beoogde het verschil tussen flex en vast werk te verkleinen, maar de resultaten blijken in veel opzichten teleurstellend (Houweling, Keulaards, \& Kruit, 2016). Het kabinet Rutte-III wil vast werk minder vast maken en flexwerk minder flex, en meer mensen aan het werk krijgen in contracten voor onbepaalde tijd (Regeerakkoord 2017-2021; VVD, CDA, D66, \& ChristenUnie, 2017). In april 2018 heeft

* Olaf Tijhuis is student Recht en Economie, Faculteit der Rechtsgeleerdheid, Universiteit Leiden. Kees Goudswaard is werkzaam bij de Afdeling Economie, Faculteit der Rechtsgeleerdheid, Universiteit Leiden. E-mail: k.p.goudswaard@law.leidenuniv.nl. 
minister Koolmees het wetsvoorstel Arbeidsmarkt in Balans ingediend met een aantal maatregelen die ertoe moeten bijdragen om de doelen uit het regeerakkoord te realiseren, waaronder een versoepeling van het ontslagrecht, een verruimde proeftijd en een aanpassing van de ketenbepaling. Met dit wetsvoorstel neemt het kabinet afstand van de door het vorige kabinet ingevoerde WWZ.

In andere Europese landen wordt - zij het in iets mindere mate - ook geworsteld met het probleem van een duale arbeidsmarkt. In dat verband is in een aantal landen ook uitgebreid door politiek en wetenschap gekeken naar de invoering van een uniform arbeidscontract als oplossing voor het genoemde probleem. In de meest vergaande vorm gaat het om de vervanging van alle huidige arbeidscontracten door één contract, dat voor onbepaalde tijd is. De (ontslag)bescherming loopt in zo'n contract op met de duur van de dienstbetrekking en zal in principe beter zijn dan bij de huidige tijdelijke contracten, maar minder dan bij de huidige vaste contracten.

In Nederland is de aandacht voor deze optie vooralsnog beperkt. Baarsma (2015) pleit al enige jaren voor de afschaffing van de huidige contracten voor onbepaalde tijd en invoering van nieuwe contracten met een looptijd van bijvoorbeeld 5 jaar. Dat zou werknemers meer zekerheid geven dan de huidige tijdelijke contracten en hen stimuleren om te investeren in hun arbeidsproductiviteit. Werkgevers zouden worden gestimuleerd om een leven lang leren te ondersteunen. D66 (2016) stelt in haar verkiezingsprogramma toe te willen naar één arbeidsrechtelijk regime voor alle werknemers, waarbij slechts het contract voor onbepaalde tijd bestaat. Bij dit voorstel hoort een ingrijpende vereenvoudiging van het ontslagrecht. Het Centraal Planbureau noemt het uniforme contract als beleidsoptie, maar geeft aan dat er nog te weinig wetenschappelijk onderzoek beschikbaar is om een afweging te maken van de voor- en nadelen van deze optie (CPB, 2015, p. 141-142).

In dit artikel analyseren wij de beschikbare literatuur over de vormgeving, effecten en mogelijke barrières van een uniform arbeidscontract. Vervolgens besteden we aandacht aan concrete voorstellen voor een uniform contract in een aantal Europese landen. Daaruit kunnen we conclusies trekken over de vraag of dit ook voor Nederland een serieuze beleidsoptie zou kunnen zijn.

Het artikel kent de volgende opbouw. Allereerst wordt de flexibilisering op de Nederlandse arbeidsmarkt in kaart gebracht, waarbij wordt gekeken naar de voor- en nadelen van flexibel werk en naar het Europese perspectief. Daarna vindt er een analyse plaats van vormgeving en effecten van een uniform arbeidscontract. In het volgende onderdeel worden voorstellen besproken voor invoering van een uniform arbeidscontract in Frankrijk, Italië en Spanje. Ten slotte worden uit deze analyses conclusies getrokken ten aanzien van de relevantie van een uniform arbeidscontract voor de Nederlandse arbeidsmarkt.

\section{Flexibilisering in Nederland en Europa}

Er is sprake van flexibiliteit op de arbeidsmarkt als werkenden en werkgevers geen vaste contractrelatie hebben. Tot de flexibele schil behoren werknemers op 
basis van een flexibel arbeidscontract (uitzendkrachten, oproepkrachten, nulurencontracten, enzovoort) en zzp'ers.

Figuur 1 toont de ontwikkeling van de flexibele schil in Nederland. Zowel het aantal flexibele contracten als het aantal zzp'ers heeft een sterke groei laten zien.

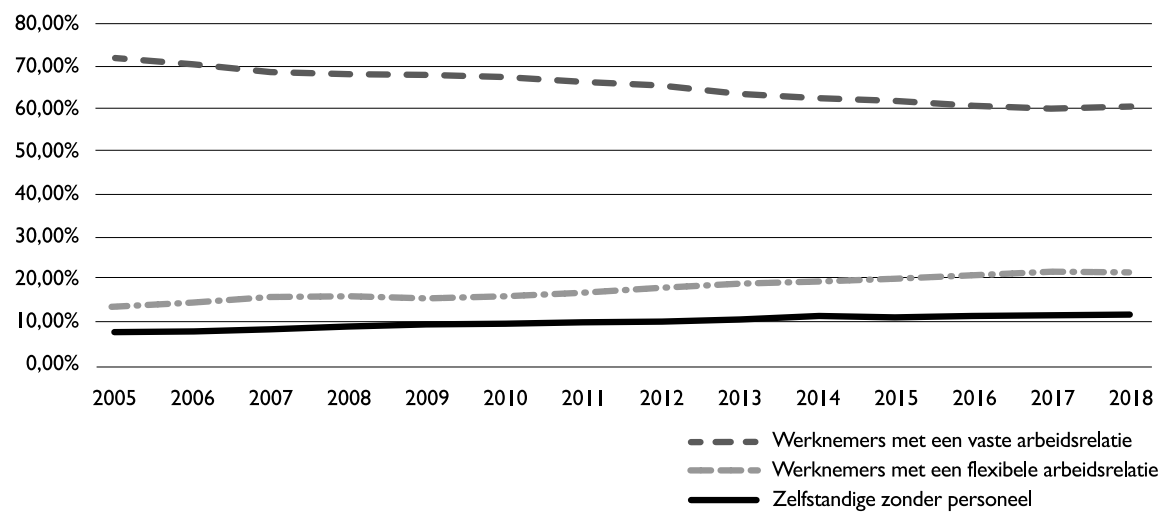

Figuur 1 Samenstelling werkenden in Nederland: 2005-2018 (Bron: CBS, 2018)

De flexibilisering is ongelijk verdeeld (Bolhaar, Brouwers, \& Scheer, 2016). Flexibele contracten komen het meest voor onder vrouwen, laagopgeleiden, thuiswonende kinderen en mensen met een migratieachtergrond. Mannen en hoogopgeleiden hebben een relatief hoge kans om zzp'er te worden. Daarnaast is er een scheve verdeling van werknemers over de verschillende sectoren. Zo kent de horecasector met $51 \%$ een groot aandeel flexibele werknemerscontracten, terwijl dit aandeel in de sector onroerend goed slechts $9 \%$ is (Scheer, De GraafZijl, \& Hoekstra, 2016). Toch verspreidt de flexibilisering zich ook meer. Vrouwen, jongvolwassenen, lager- en middelbaaropgeleiden worden sneller zzp'er. Daarnaast komen flexibele contracten steeds vaker voor bij middelbaar- en hogeropgeleiden, terwijl de leeftijd van flexibele werknemers stijgt. Kortom, de flexibilisering raakt steeds meer mensen op de arbeidsmarkt (Kremer, Went, \& Knottnerus, 2017). Vanuit theoretisch oogpunt kan men niet stellen welk type contract - vast of flex - te prefereren valt boven de ander, of wat het optimale aantal flexibel werkenden is in een economie. Flexibel werk kent voordelen en nadelen (Euwals et al., 2016, p. 12). Een eerste voordeel is dat een flexibele arbeidsmarkt de mogelijkheid biedt om mee te bewegen met de veranderende economie, waarbij werkgevers flexibele contracten inzetten om fluctuaties in het werkaanbod op te vangen (Goudswaard, Van Wijk, \& Verbiest, 2014). Verder is flexibele arbeid goedkoper voor bedrijven: de huidige wet- en regelgeving leidt ertoe dat er kostenen risicoverschillen zijn ontstaan tussen arbeidsrelaties (Chkalova, Goudswaard, Sanders, \& Smits, 2015). Daarnaast zijn redenen voor de inzet van flexibele arbeid het inhuren van specifieke kennis en opvang van ziekte. Ten slotte creëert de flexibilisering van de arbeidsmarkt meer mogelijkheden voor werknemers om 
op een laagdrempelige manier werkervaring op te doen en hun eigen voorkeuren te volgen (Van den Brakel \& Kösters, 2016).

Een van de nadelen van flexibel werk is het gebrek aan scholing. Werkgevers investeren minder snel in scholing voor flexibel werkenden dan voor het vaste personeel, terwijl flexibele werknemers en zzp'ers in de meeste gevallen niet over de middelen beschikken om zelfstandig te investeren in scholing. Verder is het nadelig dat de flexibilisering verschillende vormen van onzekerheid met zich meebrengt. Om te beginnen is er sprake van inkomensonzekerheid onder flexwerkers. De kans op armoede onder flexwerkers is driemaal hoger dan onder werknemers met een vast contract (Van den Brakel \& Kösters, 2016). Verder is er bij flexwerkers sprake van baanonzekerheid: de kans op werkloosheid is onder flexwerkers driemaal hoger dan onder werknemers in vaste dienst (Van Echtelt, Croezen, Vlasblom \& De Voogd-Hamelink, 2016). Ten slotte kennen flexwerkers ook relatief weinig ontslagbescherming. Vergeleken met andere Europese landen is de ontslagbescherming voor werknemers in vaste dienst relatief hoog en voor flexibele werknemers relatief laag in Nederland (OECD, 2013). Dit beeld is met name ook terug te zien in Frankrijk en Italië. Opvallend genoeg kent Spanje een relatief geringe ontslagbescherming, terwijl het net als Nederland, Frankrijk en Italië een land is met een hoog aandeel tijdelijke werknemers (Chkalova et al., 2015). Dit verschil in ontslagbescherming benadrukt het gesegmenteerde karakter van de Nederlandse arbeidsmarkt. Het kabinet Rutte-III wil hier overigens verandering in aanbrengen, onder meer door de transitievergoeding al te laten ingaan vanaf de start van het dienstverband (VVD et al., 2017).

Een probleem is dat de voordelen van flexibel werk breed neerslaan in de samenleving, terwijl het grootste deel van de nadelen terecht komt bij de zwakkere groepen op de arbeidsmarkt (Euwals et al., 2016). Vooral oudere en laagopgeleide flexibele werknemers blijven achter in vergelijking met andere groepen werkenden met een vergelijkbare arbeidsmarktpositie. Bovendien kennen mensen met een laag opleidingsniveau vaak een lage doorstroom vanuit een flexibel contract, waardoor zij deze nadelen gedurende een lange periode ondervinden. Het effect is dus dat groepen met een zwakkere arbeidsmarktpositie dankzij de flexibilisering in een slechtere positie terecht komen, terwijl het huidige stelsel van sociale zekerheid hen minder effectief weet te bereiken (Flier, 2016). De flexibilisering van de arbeidsmarkt is een ontwikkeling die zich ook elders in Europa heeft voorgedaan. Maar figuur 2 laat zien dat Nederland tot de koplopers behoort. Van de in figuur 2 opgenomen landen kent Nederland na Spanje het hoogste percentage flexibele contracten. De groei van het aandeel flexibele contracten in de periode 1997-2014 was in Nederland het hoogst, samen met Portugal. Het Verenigd Koninkrijk heeft het laagste aandeel flexibele contracten en dit percentage laat ook geen toename zien. 


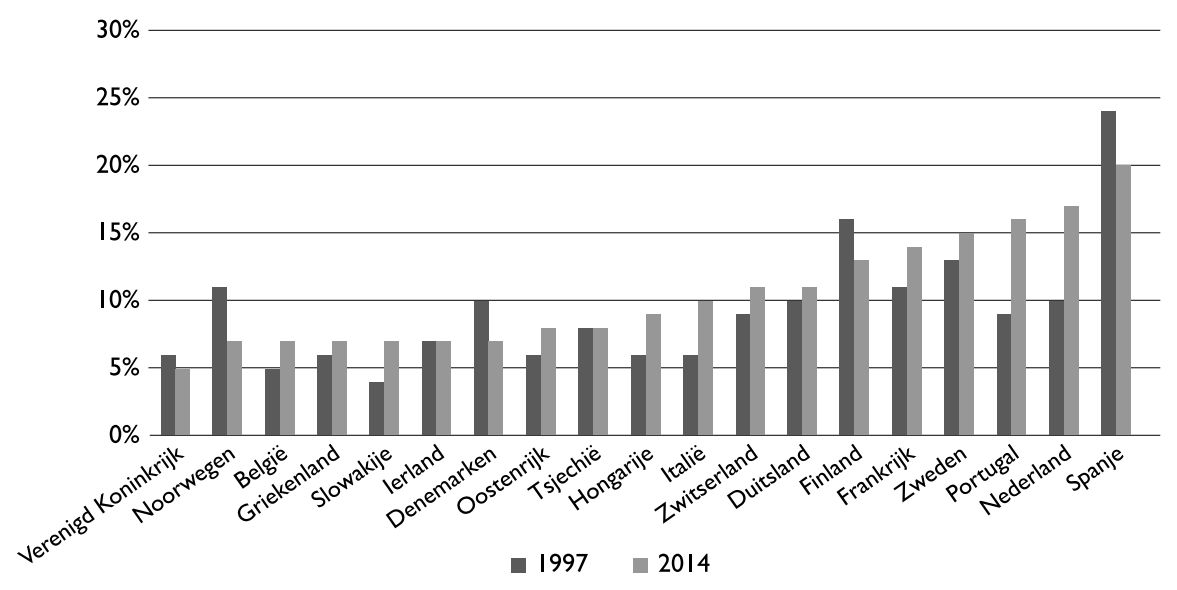

Figuur 2 Aandeel flexibele arbeidscontracten in Europa: 1997-2014 (Bron: Hoekstra, Euwals, Arsova, \& Berkhout, 2016, p. 7)

Dualisme op de arbeidsmarkt is met name terug te zien in Zuid-Europese landen. Net zoals in Nederland brengt dit allerlei problemen met zich mee, waaronder grote verschillen in bescherming en zekerheid, en negatieve effecten op de werkloosheid en het menselijk kapitaal (Nawid, Dolado, \& Lalé, 2015). Deze problematiek heeft tot een Europees debat geleid over het herontwerpen van de duale arbeidsbescherming. Dit resulteerde in een voorstel van de Europese Commissie voor de invoering van een uniform arbeidscontract. In het vervolg van dit artikel wordt dit contract verder geanalyseerd.

\section{Hoofdlijnen van een uniform arbeidscontract}

De hiervoor beschreven problemen op de Nederlandse arbeidsmarkt, maar ook elders, hebben vooral te maken met de grote verschillen die zijn ontstaan in bescherming tussen vaste en flexibele werknemers. Een mogelijke oplossing om dit duale systeem aan te passen is de invoering van één type contract voor werknemers op de arbeidsmarkt: een uniform arbeidscontract. Er zijn verschillende manieren om de contractvormen voor werknemers op de arbeidsmarkt om te vormen tot een enkel soort arbeidscontract (OECD, 2014, p. 188). De eerste mogelijkheid is het verwijderen van alle flexibele contractvormen en het behouden van het bestaande vaste contract voor onbepaalde tijd als enige contractvorm (Gleize, 2011). Omdat het grootste deel van de Europese arbeidsmarkten een relatief grote flexibele schil kent, zou dit betekenen dat alle bedrijven hun beleid en strategieën ingrijpend moeten aanpassen (Lepage-Saucier, Schleich, \& Wasmer, 2013). Bovendien zou het gevolg hiervan zijn dat de werkgelegenheid in een economische neergang snel daalt en in economisch goede tijden een 
geringe stijging kent (Casala \& Perulli, 2014). Kortom, er is behoefte aan flexibiliteit.

Een tweede mogelijkheid bestaat uit het vervangen van alle bestaande contractvormen voor werknemers door een uniform arbeidscontract dat tussen het flexibele en vaste contract in ligt. In de meeste voorstellen in de literatuur gaat men uit van deze variant. Het uniforme arbeidscontract zoals voorgesteld door de Europese Commissie lijkt het meest representatief voor de voorstellen die voorkomen in de literatuur (Europese Commissie, 2011; Casala \& Perulli, 2014, p. 37). Er zijn een aantal kenmerken van dit contract te onderscheiden, die hierna zullen worden uitgewerkt. Het idee is om een uniform arbeidscontract toe te passen voor nieuwe arbeidsovereenkomsten die worden afgesloten. Dit uniforme contract zal dus niet van toepassing zijn op de groep zzp'ers, aangezien deze groep flexibel werkenden dan geen zelfstandigen meer zijn. Verder zou het uniforme arbeidscontract een onbepaalde duur moeten kennen. Echter, anders dan de bestaande vaste contracten voor onbepaalde tijd, kent het uniforme arbeidscontract na de proeftijd een instapfase met een tijdens die fase geleidelijke verhoging van de ontslagbescherming naarmate het dienstverband langer voortduurt. Daarna volgt een stabiliteitsfase. De relatief lange instapfase heeft als doel dat werkgever en werknemer beter kunnen inschatten of een baan voor beide partijen geschikt is. Tijdens deze instapfase kan de werknemer zonder gegronde reden worden ontslagen, maar tegen een naarmate het contract vordert steeds hogere ontslagvergoeding. De toenemende ontslagbescherming naarmate het arbeidscontract vordert zorgt voor meer baanzekerheid en inkomenszekerheid voor de werknemer. Deze toenemende bescherming heeft niet per se een negatief effect op de werkgever, omdat onzekerheden over de geschiktheid van de werknemer voor de baan kunnen worden opgelost tijdens de instapfase. Blanchard en Tirole (2003a, p. 39) stellen dat deze fase lang genoeg moet zijn om te kijken of er een goede match is tussen werknemer en werkgever, maar kort genoeg om het voor werkgevers onaantrekkelijk te maken om werknemers snel te rouleren op een bepaalde baan. De instapfase moet ook voldoende lang zijn om de werkgever te stimuleren om te investeren in scholing van de werknemer. Tijdens de stabiliteitsfase is er sprake van gelijkblijvende rechten op een ontslagvergoeding. Dit betekent dat bij het uniform contract de ontslagvergoeding bij een lang dienstverband doorgaans lager zal zijn dan bij de huidige vaste contracten. Dat zou moeten bijdragen aan minder dualiteit op de arbeidsmarkt.

Het uniforme arbeidscontract kent ook juridische bescherming. Hierbij gaat het om alle wettelijke regels met betrekking tot beëindiging van de arbeidsovereenkomst, zoals de opzegtermijn en de opzeggingsprocedure. De mate van juridische bescherming van het arbeidscontract kan verschillen afhankelijk van de verschillende nationale systemen in landen en politieke voorkeuren (Casala \& Perulli, 2014). Verder kent het uniform arbeidscontract nog een aantal overige rechten, zoals het recht op werkloosheidsbescherming en pensioenopbouw, die net als de financiële en juridische bescherming progressief opbouwen naarmate het contract de stabiliteitsfase bereikt. 


\section{Effecten en belemmeringen}

Er kunnen zowel positieve als negatieve economische effecten optreden als gevolg van de invoering van een uniform arbeidscontract. Deze effecten zijn sterk afhankelijk van de arbeidsmarkt waar de invoering plaatsvindt. Uitgaande van een arbeidsmarkt met kenmerken van dualisme kunnen er de volgende potentiële effecten optreden. Bij een uniform arbeidscontract wordt de onzekerheid van het tijdelijke contract bij werkgevers en werknemers verminderd, en ontstaan er sterkere prikkels om te investeren in menselijk kapitaal (Lepage-Saucier, Schleich, \& Wasmer, 2013). De werknemer heeft een sterkere behoefte om te investeren in zichzelf, omdat dit zal leiden tot een betere prestatie en langer behoud van de baan. Dat biedt vervolgens ook meer bescherming en zekerheid. Voor de werkgever is het aantrekkelijk om te investeren in scholing voor de werknemer, omdat dit de arbeidsproductiviteit verhoogt. Omdat de werknemer bij de huidige tijdelijke contracten in de meeste gevallen maar kort bij de werkgever in dienst blijft, is het vaak risicovol voor de werkgever om in de werknemer te investeren. Met de toenemende bescherming bij een uniform arbeidscontract is de drempel voor de werkgever lager om te investeren in de werknemer, aangezien de kans groter is dat de werknemer lang in dienst blijft (Casala \& Perulli, 2014). Als een uniform contract leidt tot meer investeringen in menselijk kapitaal, zal de arbeidsproductiviteit stijgen, wat een positief effect heeft op de economische groei (Pérez \& Osuna, 2014).

Verder zal de invoering van een uniform contract waarschijnlijk een positief effect hebben op de werkgelegenheid. Ten eerste neemt de baanvernietiging af, want vanwege de hogere ontslagkosten na een aantal jaar bij een uniform arbeidscontract in vergelijking met het tijdelijke contract is er voor werkgevers een grotere drempel om het contract te vernietigen. Verder is vanwege de instapfase de drempel voor werkgevers lager om mensen aan te nemen en is de duur van een contract gemiddeld langer, wat een positief effect heeft op de werkgelegenheid (Gete \& Porchia, 2011).

Er kunnen zich ook een aantal negatieve effecten voordoen ten gevolge van de invoering van een uniform arbeidscontract. Enerzijds biedt het uniforme contract werkgevers flexibiliteit, omdat gedurende de relatief lange instapfase werknemers zonder gegronde reden tegen relatief lage kosten kunnen worden ontslagen (Lepage-Saucier et al., 2013). Anderzijds neemt de flexibiliteit bij de werving van werknemers af. Momenteel kunnen werkgevers met vaste en flexibel werkenden variëren in de samenstelling van hun personeelsbestand. Bij één enkel type contract kunnen bedrijven nog maar één soort contract aanbieden, terwijl er allerlei redenen zijn om mensen voor bepaalde zaken tijdelijk in dienst te nemen (Gete \& Porchia, 2011). Verder kan de toegenomen ontslagbescherming voor tijdelijke werknemers ertoe leiden dat de mobiliteit op de arbeidsmarkt afneemt en dat er misallocaties ontstaan (Lepage-Saucier et al., 2013).

Naast potentiële positieve effecten kan een uniform arbeidscontract ook negatieve effecten hebben op de werkgelegenheid. Hoewel de baanvernietiging van tijdelijke contracten naar verwachting zal afnemen, zal de baanvernietiging in vergelijking tot de huidige vaste contracten toenemen. Dit komt omdat deze contracten nu een lagere ontslagbescherming kennen, wat leidt tot gemakkelijker ontslag en tijdens een recessie een negatief effect heeft op de werkgelegenheid (Pérez \& 
Osuna, 2011). Verder zorgt het schrappen van tijdelijke contracten op de arbeidsmarkt voor een vermindering van de werkgelegenheid, als de tijdelijke contracten niet worden omgezet in het nieuwe contract.

Ten slotte is een bezwaar tegen het prototype van het uniform contract dat er discontinuïteit optreedt als gevolg van de overgang van de instapfase naar de stabiliteitsfase. Er kan een prikkel voor werkgevers zijn om werknemers voor het ingaan van de stabiliteitsfase te ontslaan, als dat nog relatief gemakkelijk zonder gegronde redenen kan (OECD, 2014). Daarom zijn er ook voorstellen gedaan voor een uniform contract zonder onderscheid in fases (Lepage-Saucier et al., 2013). Daarbij zouden de rechten op ontslagvergoeding continu in de tijd moeten toenemen en zouden de ontslagregels makkelijker zijn dan bij de huidige vaste contracten, maar minder makkelijk dan in de instapfase van het hiervoor besproken uniform contract.

$\mathrm{Al}$ met al is er vanuit theoretisch perspectief geen eenduidig antwoord te geven welke effecten als gevolg van de invoering van een uniform arbeidscontract zullen overheersen. Een en ander zal ook afhangen van de vormgeving van een dergelijk contract.

De transitie naar een eventueel uniform contract zal veel aandacht vragen. Het huidige duale systeem is diepgeworteld in de meeste landen. Omdat de arbeidsmarkt ingrijpend zou worden gewijzigd door invoering van een uniform arbeidscontract, ligt het voor de hand dat dit contract eerst alleen zou gaan gelden voor de nieuwe arbeidsovereenkomsten die worden afgesloten. De transitie van een arbeidsmarkt die momenteel vaste contracten en vormen van tijdelijk werk kent naar een arbeidsmarkt die nog slechts één type contract kent, is een overgang die waarschijnlijk lang zal duren, waarbij er ook verschillende mogelijke barrières zijn. Gedurende de overgangsperiode is het van belang dat er een aantal prikkels voor werkgevers en werknemers gecreëerd worden die de overgang zullen bevorderen (Casala \& Perulli, 2014). Vanuit het perspectief van de werkgever is het van belang dat de kosten die gepaard gaan met een uniform arbeidscontract lager zijn dan andere vormen van vaste contracten, zodat het aantrekkelijker is voor werkgevers om dit contract aan te bieden dan vaste contracten. Tegelijkertijd moeten de kosten verbonden aan tijdelijke contracten verhoogd worden zodat werkgevers een prikkel ervaren om deze contracten niet meer aan te bieden. Wat betreft prikkels voor werknemers is een mogelijkheid dat aan werknemers subsidies worden verstrekt indien zij een uniform contract afsluiten.

Bij de invoering van een uniform arbeidscontract bestaan er ook potentiële juridische barrières. Een dergelijk contract zou in strijd kunnen zijn met de ILO Termination of Employment Convention no. 158. Ook nationale arbeidsrechtelijke wetten kunnen de invoering van één type arbeidscontract belemmeren of zelfs tegenhouden. Veel arbeidswetgeving in Europese landen kent strenge regels met betrekking tot de inhoudelijke gronden voor ontslag en de hieraan verbonden processuele vereisten (Lepage-Saucier et al., 2013). Met name dit kan een obstakel zijn, omdat een nieuw uniform arbeidscontract een relatief soepel ontslag zal kennen. 
In de volgende paragrafen bespreken we concrete voorstellen voor een uniform contract in respectievelijk Frankrijk, Italië en Spanje. Deze landen kennen immers net als Nederland een duale arbeidsmarktstructuur. Wegens bepaalde problemen die dit met zich meebrengt is er in deze landen veel aandacht voor deze beleidsoptie. Overigens zou een vergelijking met bijvoorbeeld het Verenigd Koninkrijk ook interessant zijn, omdat daar juist sprake is van een laag aantal flexibele contracten (Chkalova et al., 2015). Maar daar staat tegenover dat er in het VK relatief weinig ontslagbescherming is bij vaste contracten en dat er een hoge arbeidsmobiliteit is (Muffels, 2013). De arbeidsmarkt in het VK heeft dus nauwelijks een duale structuur en er is in principe voldoende flexibiliteit. Dat kan verklaren waarom er in het VK, anders dan in Frankrijk, Italië en Spanje, weinig tot geen belangstelling bestaat voor een uniform arbeidscontract.

\section{Frankrijk}

De Franse arbeidsmarkt kenmerkt zich door strenge regelgeving met betrekking tot ontslag van werknemers in vaste dienst en veelvuldig gebruik van tijdelijke contracten (Venn, 2009). De combinatie van hoge werkloosheid en toenemend dualisme hebben de afgelopen decennia geleid tot debatten over hervormingen op de Franse arbeidsmarkt. Hierbinnen lag de nadruk met name op de invoering van nieuwe type contracten (Guillaud \& Marx, 2013).

In augustus 2005 introduceerde de Franse overheid een nieuw arbeidscontract, het Contrat Nouvelle Embauce (CNE) voor bedrijven met maximaal twintig werknemers (Lepage-Saucier et al., 2013). Dit contract gold nog steeds voor onbepaalde tijd, maar gaf werkgevers meer speelruimte met betrekking tot het ontslag van werknemers gedurende de eerste twee jaar van het contract, doordat ontslag zonder gegronde reden mogelijk was. In geval van ontslag kreeg de werknemer een ontslagvergoeding die gelijk was aan $8 \%$ van het salaris dat de werknemer verdiend had sinds het begin van de arbeidsovereenkomst. Het soepele ontslag gedurende de eerste twee jaar en de oplopende ontslagvergoeding zijn elementen die overeenkomen met de instapfase van het eerder beschreven voorstel voor een uniform arbeidscontract.

Het CNE werd gebruikt als model voor het Contrat Première Embauche (CPE), een contract dat de Franse overheid in 2006 wilde invoeren. Het CPE was bedoeld om het CNE te generaliseren, zodat het ook gebruikt kon worden voor bedrijven met meer dan twintig werknemers in dienst, zolang de werknemer jonger was dan 26 jaar. Doel was om tot meer vaste contracten te komen door werkgevers meer flexibiliteit te geven voordat zij de werknemer permanent in dienst moesten nemen (Casala \& Perulli, 2014).

Beide type contracten zijn echter nooit geïmplementeerd. Van het CPE is afgezien na hevige protesten van allerlei partijen en het CNE werd door de Franse rechter in strijd verklaard met de ILO Termination of Employment Convention no. 158. Desondanks bleef het verkleinen van de verschillen tussen vaste en tijdelijke contracten een punt op de Franse politieke agenda. Het creëren van een uniform arbeidscontract, het Contrat de Travail Unique (CTU), dat de twee bestaande contractvormen zou gaan vervangen was onderdeel van het verkiezingsprogramma van Nicolas Sarkozy voor de Franse presidentsverkiezingen in 2007. Het voorstel 
van Sarkozy was gebaseerd op twee rapporten die al eerder uitgebracht waren, het rapport van Blanchard en Tirole (2003b), en het rapport van Cahuc en Kramarz (2004).

Het voorstel voor invoering van een CTU ging om een uniform arbeidscontract voor onbepaalde tijd en kende twee belangrijke elementen (Blanchard \& Tirole, 2003b). Ten eerste konden werkgevers werknemers zonder gegronde reden ontslaan, uitgezonderd discriminatie. Daar stond tegenover dat werkgevers een solidariteitsbijdrage moesten betalen aan de Franse staat en een ontslagvergoeding aan de werknemer. Beide vergoedingen namen toe naarmate de werknemer langer in dienst was (Cahuc \& Kramarz, 2004). Het CTU is tot op heden nog niet ingevoerd in Frankrijk, maar het blijft wel onderdeel van het politieke debat. De voornaamste reden dat het tot nu toe beperkt is gebleven tot een voorstel is dat het brede maatschappelijke draagvlak vereist voor de invoering ontbreekt. De vakbonden en de IAO zijn van mening dat het CTU in strijd is met het ILO Termination of Employment Convention no. 158, omdat deze conventie een gegronde reden voor ontslag vereist. Verder zijn werkgevers kritisch, omdat zij het voordeel van de keuzemogelijkheid tussen verschillende contracten en de daarmee gepaard gaande flexibiliteit zouden verliezen (Casala \& Perulli, 2014).

\section{Italië}

Italië is binnen Europa een van de bekende voorbeelden van dualisme op de arbeidsmarkt, met als gevolg dat er al decennialang een debat gaande is over structurele arbeidsmarkhervormingen. In de afgelopen vijftien jaar heeft de Italiaanse arbeidsmarkt inderdaad al meerdere ingrijpende hervormingen ondergaan. Deze hervormingen hebben het dualisme echter niet doorbroken. Daarom zijn er ook meerdere voorstellen gedaan voor de invoering van een uniform arbeidscontract, het nuovo contratto per tutti (Garibaldi \& Taddei, 2013).

Het eerste concrete voorstel voor de invoering van één enkel type arbeidscontract kwam van Boeri en Garibaldi (2008) en was vergelijkbaar met het voorstel van de Europese Commissie. Het ging om een contract voor onbepaalde tijd met toenemende ontslagbescherming naarmate het contract vordert. In het Italiaanse voorstel bestaat het contract uit een startfase van drie jaar, waarna er een stabiliteitsfase volgt. Gedurende de startfase kan de werkgever de werknemer zonder gegronde reden ontslaan, tegen een financiële compensatie die toeneemt met vijf dagen salaris per maand in dienst. $\mathrm{Na}$ drie jaar wordt een maximum compensatie van zes maanden salaris bereikt. Tijdens deze fase is de herstelclausule uit artikel 18 Italiaanse arbeidswetgeving (Statuto dei Lavaratori) niet van toepassing. Volgens dit artikel heeft een werknemer recht op volledig herstel van de arbeidsovereenkomst indien de rechter het ontslag van een werknemer ongeldig verklaart (Fana, Guarascio, \& Cirillo, 2015). Zodra de stabiliteitsfase intreedt is dit artikel weer van toepassing. Ten slotte wordt voorgesteld om bij een aantal specifieke situaties, zoals seizoensarbeid, tijdelijke contracten te handhaven.

Er zijn in Italië concrete wetsvoorstellen gedaan voor de invoering van een uniform arbeidscontract. Bij deze voorstellen werd het model van Boeri en Garibaldi, zoals hierboven beschreven, grotendeels gevolgd. Er zijn echter verschillen op het punt van de ontslagvergoedingen (Fana et al., 2015). Deze zijn net als in 
andere voorstellen progressief, maar wel afhankelijk van de reden voor ontslag. Als het gaat om een economische reden is de bescherming voor de werknemer binnen dit contract lager dan wanneer er geen gegronde reden is voor ontslag. Hiermee wordt beoogd een betere balans te vinden tussen flexibiliteit voor de werkgever en zekerheid voor de werknemer.

Tot op heden is een uniform arbeidscontract nog niet ingevoerd in Italië. De voornaamste reden is dat net als in Frankrijk het brede maatschappelijke draagvlak vereist voor de invoering ontbreekt (Garibaldi \& Taddei, 2013). De Italiaanse werkgeversorganisatie geeft aan dat zij het te beperkt vindt om één vorm van toetreding te hebben tot de arbeidsmarkt. Italiaanse werkgevers hebben wegens het snel veranderende economische klimaat behoefte aan flexibiliteit en keuzemogelijkheden bij het aanbieden van contracten. Daarnaast zijn vakbonden in Italië van mening dat de instapfase van drie jaar een te lange duur kent, waardoor er te weinig zekerheid wordt geboden aan werknemers.

Wel zijn er naar aanleiding van het debat en de voorstellen voor de invoering van een uniform arbeidscontract een aantal belangrijke hervormingen doorgevoerd om het dualisme op de Italiaanse arbeidsmarkt te verminderen. In 2012 werd het aantal soorten contracten teruggebracht van 40 naar 8 . Daarnaast werd de maximale duur van tijdelijke contracten verlengd en werden deze contracten 'duurder' gemaakt voor werkgevers (Lepage-Saucier et al., 2013). In 2014 introduceerde de Italiaanse overheid een nieuw contract op de arbeidsmarkt, het contratto a tutele crescenti. Dit contract voor onbepaalde tijd kent een lagere herstelverplichting dan vereist volgens het Statuto dei Lavaratori, conform het model van Boeri en Garibaldi voor een uniform arbeidscontract.

\section{Spanje}

Tijdens de financiële crisis werd duidelijk dat de Spaanse duale arbeidsmarkt slecht presteerde. Spanje kende binnen de EU het hoogste percentage banenvernietiging, met name van tijdelijk banen. Dit heeft ertoe geleid dat het werkloosheidspercentage in die periode enorm is gestegen, meer dan in de meeste andere landen. Als een van de belangrijkste oorzaken werd de duale arbeidsbescherming gezien, waarbij er een aanzienlijk verschil was in ontslagvergoeding tussen vaste en flexibele contracten (Costain, Jimeno, \& Thomas, 2010).

Net als in Frankrijk en Italië ontstond er in Spanje een uitgebreid debat over hervormingen van de arbeidsmarkt. In dat kader werd door 100 Spaanse economen een manifest over hervorming van de arbeidsmarkt ondertekend, waarin wordt voorgesteld om een uniform arbeidscontract in te voeren (Pérez \& Osuna, 2011). Het voorstel kent twee belangrijke elementen. Het gaat ten eerste om een contract voor onbepaalde tijd, met een bepaalde periode waarin de werkgever de werknemer zonder gegronde reden kan ontslaan, uitgezonderd discriminerende redenen voor ontslag. Gedurende deze periode is er recht op een ontslagvergoeding, die toeneemt naarmate het contract vordert en die na deze periode een bepaald maximum bereikt. Net als het voorstel van de Europese Commissie en het Italiaanse voorstel geeft het Spaanse voorstel ook twee concrete fases aan: de instapfase, met het gemakkelijke ontslag en de progressieve ontslagvergoeding, en vervolgens de overgang naar de stabiliteitsfase (Abadie, 2009). In tegenstelling 
tot het Italiaanse voorstel wordt de duur van de instapfase niet aangegeven in het Spaanse voorstel.

In de Spaanse literatuur zijn verschillende onderzoeken te vinden naar de potentiële effecten op de economie als gevolg van de invoering van een uniform arbeidscontract. Hoewel de uitkomsten van deze onderzoeken wegens verschillende uitgangspunten op bepaalde punten verschillen, zijn er een aantal effecten die in de meeste onderzoeken terugkomen. Ten eerste is de verwachting dat de werkloosheid als gevolg van de invoering van een uniform arbeidscontract in Spanje zal afnemen (Nawid et al., 2015). Daarnaast komt er meer evenwicht in de baanvernietiging, omdat het kostbaarder wordt om de huidige flexibele werknemers te ontslaan en relatief gemakkelijker wordt om vaste werknemers te ontslaan. Naar verwachting zal de totale baanvernietiging afnemen. Verder zal de werkgelegenheid in Spanje waarschijnlijk toenemen, omdat de te verwachten te betalen ontslagkosten voor werkgevers afnemen (Pérez \& Osuna, 2011). Bovendien is de verwachting dat het schrappen van tijdelijke contracten op de Spaanse arbeidsmarkt ertoe zal leiden dat bedrijven sneller investeren in het menselijk kapitaal van hun werknemers, wat een positief effect heeft op de arbeidsproductiviteit en de economische groei (Pérez \& Osuna, 2014). Hier kan weer tegen in worden gebracht dat minder productieve werknemers minder gemakkelijk kunnen worden ontslagen onder het uniforme arbeidscontract dan onder de tijdelijke contracten, wat een negatief effect heeft op de arbeidsproductiviteit (Nawid et al., 2015).

Ook in Spanje is het uniforme arbeidscontract tot op heden niet ingevoerd. Om te beginnen zijn er omvangrijke juridische barrières. Zo kan het uniforme arbeidscontract in strijd zijn met het gelijkheidsbeginsel uit artikel veertien van de Spaanse grondwet, omdat er verschillen in bescherming en behandeling ontstaan met de huidige werknemers. Verder speelt in het Spaanse debat ook het eerder genoemde probleem dat een uniform arbeidscontract in strijd is met met de ILO Termination of Employment Convention no. 158. Bovendien is de angst bij de Spaanse vakbonden dat er segmentatie ontstaat tussen werknemers met vaste contracten voor en na de introductie van een uniform arbeidscontract, en dat de baanonzekerheid juist toeneemt. Ten slotte geven de werkgevers aan dat zij op de dynamische Spaanse arbeidsmarkt de mogelijkheid willen behouden om bij de werving van werknemers verschillende soorten contracten te kunnen aanbieden (Casala \& Perulli, 2014). Al met al ontbreekt er tot op heden net als in Frankrijk en Italië in Spanje het brede maatschappelijke draagvlak voor invoering van een uniform arbeidscontract. Wel is er naar aanleiding van de voorstellen en het debat over de invoering van een uniform arbeidscontract in maart 2012 een ingrijpende arbeidsmarkthervorming doorgevoerd. Het doel van de hervorming was om meer flexibiliteit binnen het vaste contract te creëren en het gebruik van tijdelijke contracten te beperken. Deze hervorming introduceerde een nieuw contract voor onbepaalde tijd voor bedrijven met minder dan 50 werknemers. Dit contract kent een proeftijd van één jaar, meerdere fiscale voordelen voor de werkgever bij het gebruik van dit contract en gemakkelijker ontslag om economische redenen. Het zijn elementen die vergelijkbaar zijn met onderdelen van het voorstel voor de invoering van een uniform arbeidscontract. 


\section{Slotbeschouwing: een uniform arbeidscontract in Nederland?}

De debatten in Frankrijk, Italië en Spanje laten zien dat een uniform arbeidscontract kan worden gezien als een interessante optie om in te spelen op de nadelen van de steeds grotere flexibele schil en de duale structuur van de arbeidsmarkt. In de verschillende voorstellen voor de invoering van een uniform arbeidscontract zijn er met betrekking tot de vormgeving een aantal gemeenschappelijke kenmerken te onderscheiden. Ten eerste is een uniform arbeidscontract binnen alle voorstellen een contract voor onbepaalde tijd met een instapfase van twee tot drie jaar, waarin de werkgever de werknemer zonder gegronde redenen kan ontslaan. Wel is er tijdens deze instapfase sprake van een oplopende ontslagvergoeding naarmate het dienstverband langer voortduurt. Na de instapfase bereikt de ontslagvergoeding een maximum en gaat een uniform arbeidscontract de stabiliteitsfase in. Onderzoek duidt er op dat op basis van een dergelijke vormgeving een aantal positieve effecten is te verwachten. Waarschijnlijk neemt de prikkel om te investeren in scholing voor werknemers en werkgevers toe, net als de baan- en inkomenszekerheid voor flexibel werkenden, en wordt er met een instapfase flexibiliteit geboden aan werkgevers. Er kunnen verschillende effecten op de werkgelegenheid optreden, maar per saldo zijn die effecten waarschijnlijk positief. Nadelen zijn onder meer dat de flexibiliteit van tijdelijke contracten verdwijnt en dat de discontinuiteit in het contract werkgevers mogelijk aanleiding geeft om werknemers te ontslaan voordat de stabiliteitsfase is ingetreden. Verder is de transitie naar een uniform contract mogelijk gecompliceerd, brengt die kosten met zich mee en er zijn meerdere juridische barrières. Het beschikbare onderzoek is gebaseerd op inschattingen en modelmatige berekeningen. Verder empirisch onderzoek zou noodzakelijk zijn om een scherper beeld te krijgen van de baten en kosten van een uniform arbeidscontract.

De ervaringen in Frankrijk, Italië en Spanje laten ook zien dat het maatschappelijk draagvlak voor een uniform contract niet groot is. Ten eerste zijn werkgevers in deze landen kritisch, omdat zij het voordeel van de keuzemogelijkheid tussen verschillende contracten en de daarmee gepaard gaande flexibiliteit zouden verliezen. Daarnaast is er angst bij de vakbonden dat door de relatief lange instapfase, waarin werknemers gemakkelijk kunnen worden ontslagen, de baanonzekerheid hetzelfde blijft of juist toeneemt. Ook is het maar de vraag of de vakbonden zullen instemmen met de verminderde bescherming van de huidige vaste werknemers. In plaats van de arbeidsmarkt ingrijpend aan te passen zijn er in Frankrijk, Italië en Spanje naar aanleiding van het debat over een uniform arbeidscontract wel arbeidsmarkthervormingen doorgevoerd. De focus bij deze hervormingen was vooral gericht op het bieden van meer bescherming aan flexibele contracten. Met deze hervormingen kon men een aantal problemen verbonden aan dualisme oplossen met voordelige elementen uit een uniform arbeidscontract, zonder het gehele contract met de daaraan verbonden bezwaren in te voeren.

Ook in Nederland lijkt het lastig om een breed maatschappelijk draagvlak te vinden voor de invoering van een uniform arbeidscontract. Maar ook in Nederland worden door het kabinet Rutte-III stappen gezet die elementen bevatten van de voorstellen voor een uniform arbeidscontract (VVD et al., 2017). Ten eerste wordt de ontslagbescherming voor vaste contracten net als bij het uniforme 
contract versoepeld met de invoering van een 'cumulatiegrond' voor ontslag. Verder worden de mogelijkheden voor een langere proeftijd verruimd, teneinde werkgevers binnen het vaste contract meer flexibiliteit te bieden, vergelijkbaar met de instapfase van een uniform contract. Ten slotte zal de transitievergoeding meteen vanaf het begin van de arbeidsovereenkomst gaan gelden, waardoor het voor werkgevers kostbaarder wordt om flexibele werknemers te ontslaan. Deze voorstellen zullen naar verwachting bijdragen aan meer evenwicht tussen flexibel en vast werk.

Dat neemt niet weg dat het eerder genoemde voorstel van Baarsma (2015) voor een middellang contract van bijvoorbeeld vijf jaar ook interessante elementen bevat, zij het dat dit type contract verder uitgewerkt zal moeten worden. Een dergelijk contract kan een tussenvorm zijn tussen flex en vast, en zou zowel werkgevers als werknemers kunnen stimuleren om meer te investeren in scholing. Er treedt een verschuiving op van baanzekerheid naar werkzekerheid. Dit voorstel heeft niet het nadeel dat de behoefte aan tijdelijke arbeid niet meer kan worden vervuld, omdat uitzendwerk blijft toegestaan. De Beer (2017) wijst er op dat ook nu al contracten voor 5 jaar kunnen worden afgesloten. Dat is het geval, maar na afloop van die 5 jaar houdt ofwel het dienstverband op, ofwel moet er een vast contract worden aangeboden. Dat houdt de duale structuur dus in stand. Het idee is dat het vijfjarig contract steeds verlengd moet kunnen worden. Inmiddels zijn er in de praktijk ook al afspraken gemaakt over de introductie van tussenbanen voor 4 jaar. Het moet niet worden uitgesloten dat er in de toekomst veel meer contracten van deze aard zullen worden afgesloten. Weliswaar gaat het niet om een uniform contract, maar mogelijk wel om belangrijke elementen daaruit.

\section{Literatuur}

Abadie, A., Alcalá, F., Amuedo-Dorantes, C., Alonso-Borrego, C., Andrés, J., Aurioles, J., ... Vives, X. (2009). A proposal to restart the Spanish labor market. Grupo de Discusion de Economía Laboral, FEDEA.

Baarsma, B. (2015). Over de noodzakelijke hervormingen van de arbeidsmarkt: Hoe de flexibiliserende arbeidsmarkt botst met verouderde instituties. In M. Snijder, J. Bongers, \& L. van Dijk (red.), De toekomst van werk: alles flex? Van Mierlo Symposium 2015 (pp. 14-35). Den Haag.

Blanchard, O., \& Tirole, J. (2003a). Contours of employment protection reform. MIT Working Paper 03-35. Cambridge, MA: MIT.

Blanchard, O., \& Tirole, J. (2003b). Protection de l'emploi et procedures de licenciement. Parijs: La documentation française.

Boeri, T., \& Garibaldi, P. (2008). Un nuovo contratto per tutti. Torino: Chiarelettere.

Bolhaar, J., Brouwers, A., \& Scheer, B. (2016). De flexibele schil van de Nederlandse arbeidsmarkt: Een analyse op basis van microdata. Den Haag: Centraal Planbureau.

Cahuc, P., \& Kramarz, F. (2004). Rapport au ministre de l'Économie, des Finances et de l'Industrie et au ministre de l'Emploi, du Travail et de la Cohésion sociale. Parijs: La documentation française.

Casala, G., \& Perulli, A. (2014). Towards the single employment contract: Comparative reflections. Oxford: ILO.

CBS. (2018). Gegevens werkzame beroepsbevolking: Positie in de werkkring. Den Haag: Centraal Bureau voor de Statistiek.

CPB. (2015). Kansrijk arbeidsmarktbeleid. Den Haag: Centraal Planbureau. 
Chkalova, K., Goudswaard, A., Sanders, J., \& Smits, W. (2015). Dynamiek op de Nederlandse arbeidsmarkt: De focus op flexibilisering. Den Haag: CBS, TNO.

Costain, J., Jimeno, J.F., \& Thomas, C. (2010). Employment fluctuations in a dual labour market. Documento de trabajo No. 1013. Madrid: Banco de España.

De Beer, P.T. (2017). Een tussencontract van vijf jaar: Voor welk probleem biedt dat een oplossing? Het Financieele Dagblad, 8 mei 2017.

D66. (2016). Verkiezingsprogramma 2017-2021. Den Haag.

Europese Commissie. (2011). Enhancing labour market functioning, combating segmentation: A proposal for a 'single' open-ended contract. Commission note. Brussel: Europese Commissie.

Euwals, R., De Graaf-Zijl, M., \& Van Vuren, D. (2016). Lusten en lasten ongelijk verdeeld: Verklein verschillen vast, flex en zzp. CPB Policy Brief $n r$. 14. Den Haag: Centraal Planbureau.

Fana, M., Guarascio, D., \& Cirillo, V. (2015). Working paper: Labour market reforms in Italy: Evaluating the effects of the Jobs Act. ISIGrowth.

Flier, M. (2016).Rapport werkgroep Arbeidsmarkt en Sociale Zekerheid ten behoeve van de studiegroep duurzame groei. Den Haag: Rijksoverheid.

Garibaldi, P., \& Taddei, F. (2013).Italy: A dual labour market in transition: Country case study on labour market segmentation, Employment Working Paper no. 144. Geneva: ILO.

Gete, P., \& Porchia, P. (2011). A real options analysis of dual labour markets and the single labour contract. MPRA paper no. 34055. Georgetown: Georgetown University \& IE Business School.

Gleize, C. (2011).Un CDI pour tous. Etudes November. Parijs: Institut Montaigne.

Goudswaard, A., Van Wijk, E., \& Verbiest, S. (2014). De toekomst van flex: Een onderzoek van TNO naar flexstrategieën van Nederlandse bedrijven. Den Haag: TNO.

Guillaud, E., \& Marx, P. (2013).Preferences for employment protection and the insider-outsider divide. Discussion Paper No. 7569. Bonn: Forschungsinstitut zur Zukunft der Arbeit/ Institute for the Study of Labor.

Hoekstra, K., Euwals, R., Arsova, A., \& Berkhout, E. (2016). Flexible employment in an international perspective: An empirical analysis and some country specific case studies. CPB Background Document. Den Haag: Centraal Planbureau.

Houweling, A.R., Keulaards, M.J.M.T., \& Kruit, P. (2016). Evaluatieonderzoek WWZ. Den Haag: Boom Juridisch.

Kremer, M., Went, R., \& Knottnerus, A. (2017). Voor de zekerheid: De toekomst van flexibel werkenden en de moderne organisatie van arbeid. Den Haag: Wetenschappelijke Raad voor het Regeringsbeleid.

Lepage-Saucier, N., Schleich, J., \& Wasmer, E. (2013). Moving towards a single labour contract: Pros, cons and mixed feelings. OECD Economics Department Working Papers, No. 1026. Parijs: OECD Publishing.

Muffels, R.J.A. (2013). Flexibilisering en de toegang tot de arbeidsmarkt. Tijdschrift voor Politieke Economie Digitaal, 7(4), 79-99.

Nawid, S., Dolado, J., \& Lalé, E. (2015). Moving towards a single labor contract: Transition vs. steady state. Beiträge zur Jahrestagung des Vereins für Sozialpolitik 2015: Okonomische Entwicklung - Theorie und Politik. Hamburg.

OECD. (2013). Employment Outlook 2013. Parijs: OECD Publishing.

OECD. (2014). Employment Outlook 2014. Parijs: OECD Publishing.

Pérez, J., \& Osuna, V. (2011). The effects of introducing a single open-ended contract in the Spanish labour market. Sevilla: Universidad de Sevilla, Department of Economics.

Pérez, J., \& Osuna, V. (2014). Dual labour markets and tenure distribution: Reducing severance pay or introducing a single contract. Labour Economics, 29, 1-13.

Scheer, B., De Graaf-Zijl, M., \& Hoekstra, K. (2016). De ontwikkeling van flexibele arbeid: Een sectoraal perspectief. Den Haag: Centraal Planbureau.

Van den Brakel, M., \& Kösters, L. (2016). Sociaal-economische trends: Inkomenspositie van flexwerkers. Den Haag: CBS.

Van Echtelt, P., Croezen, S., Vlasblom, J.D., \& De Voogd-Hamelink, M. (2016). Aanbod van arbeid 2016: Werken, zorgen en leren op een flexibele arbeidsmarkt. Den Haag: SCP. 
Venn, D. (2009). Legislation, collective bargaining and enforcement: Updating the OECD employment protection indicators. OECD Special, Employment and Migration Working Papers, no. 89. Parijs: OECD Publishing.

VVD, CDA, D66, \& ChristenUnie. (2017). Arbeidsmarkt en sociale zekerheid. In Vertrouwen in de toekomst: Regeerakkoord 2017-2021 (pp. 22-29). Den Haag.

\section{Towards a single labour contract?}

Temporary employment has increased substantially in many countries, causing problems and segmentation on the labour market. In this context, several proposals have been put forward to replace all existing labour contracts by a single labour contract. In this article we show how such a contract would look like and we analyze possible economic effects. Furthermore, we present an overview of the debates on a single contract in France, Italy and Spain.

In most proposals, the single contract is open-ended and has two phases: an entry phase and a stability phase. During the entry phase dismissal is relatively easy, but severance pay entitlements increase with job tenure. A single contract has pros and cons, but on balance the effects on investments in human capital and employment are probably positive. However, in the countries mentioned support for such a contract has not been very strong. This will probably also be the case in the Netherlands, but recent policy proposals to bring more balance on the labour market show similarities with elements of a uniform contract. 